\title{
Teenage Pregnancy and Its Associated Factors among School Adolescents of Arba Minch Town, Southern Ethiopia
}

\author{
Samuel Mathewos, Aleme Mekuria
}

\section{OPEN ACCESS}

Citation: Samuel Mathewos, Aleme Mekuria. Teenage Pregnancy and Its Associated Factors among School Adolescents of Arba Minch Town, Southern Ethiopia. Ethiop J Health Sci.2017; 28(3): 287

doi:http://dx.doi.org/10.4314/ejhs.v28i3.6 Received: November 29, 2017

Accepted: December 1, 2017

Published: May 1, 2018

Copyright: (C) 2018 Samuel Mathewos, et al. This is an open access article distributed under the terms of the Creative Commons Attribution License, which permits unrestricted use, distribution, and reproduction in any medium, provided the original author and source are credited.

Funding: This research is funded by Jimma University College of Public Health and Medical Sciences

Competing Interests: The authors declare that this manuscript was approved by all authors in its form and that no competing interest exists.

Affiliation and Correspondence:

${ }^{1}$ Department of Public Health, Arba Minch College of Health Sciences, Arba Minch, Ethiopia *Email:alemmekurishet@gmail.c om

\section{ABSTRACT}

BACKGROUND: Teenage pregnancy has long been a worldwide social, economic and educational concern for the developed, developing and underdeveloped countries. Studies on adolescent sexuality and pregnancy are very limited in our country. Therefore, this study aims to assess the prevalence of teenage pregnancy and its associated factors among school adolescents of Arba Minch Town.

METHODS: Institution-based, cross-sectional study was conducted from 20-30 March 2014. Systematic sampling technique was used to select a total of 578 students from four schools of the town. Data were collected by trained data collectors using a pre-tested, selfadministered structured questionnaire. Analysis was made using SPSS version 20.0 statistical packages. Multivariate logistic regression was used to identify the predictors of teenage pregnancy. RESULTS: The prevalence of teenage pregnancy among school adolescents of Arba Minch Town was 7.7\%. Being grade 11 student (AOR=4.6;95\%CI:1.4,9.3), grade 12 students $(A O R=5.8 ; 95 \%$ CI:1.3,14.4), not knowing the exact time to take emergency contraceptives $(A O R=3.3 ; 95 \%$ CI:1.4,7.4), substance use (AOR=3.1;95\%CI:1.1,8.8), living with either of biological parents $(A O R=3.3 ; 95 \% C I: 1.1,8.7)$ and poor parent-daughter interaction $(A O R=3.1 ; 95 \% C I: 1.1,8.7)$ were found to be significant predictors of teenage pregnancy.

CONCLUSIONS: This study revealed high level of teenage pregnancy among school adolescents of Arba Minch Town. A significant number of adolescent female students were at risk of facing the challenges of teenage pregnancy in the study area. School-based reproductive health education and strong parentdaughter relationships are recommended.

KEYWORDS: Adolescent, Teenage pregnancy, Risk factors, Arba Minch, School, Southern Ethiopia

\section{INTRODUCTION}

Adolescence is a transitional period from childhood to adulthood characterized by significant physiological, psychological and social changes. However, adolescent girls suffer from a disproportionate share of teenage pregnancy which is a universal public healthproblem that affects maternal and child health $(1,2)$. 
Adolescent pregnancy and childbearing is a a global health and economic challenge nowadays. Globally, about 18 million adolescent girls between 15-19 years give birth each year (adolescent birth rate was 53 births per 1,000 women). Babies born to adolescent mothers account for $11 \%$ of all births worldwide; $95 \%$ of these occur in developing countries (3).

In subSaharan Africa, in the year 2013, 101 births per 1,000 were some of the highest rates of adolescent fertility in the world (4). Among 14.3 million adolescent girls who gave birth in 2008 worldwide, one of every three was from subSaharan Africa. More than 50\% of adolescent girls give birth by the age of 20 in this region (5).

According to the EDHS 2016, 13\% of women aged 15-19 years in Ethiopia began childbearing: $10 \%$ had a live birth, and $2 \%$ were pregnant with their first child at the time of interview. The proportion of women aged 15-19 years who began childbearing rose rapidly with age, from $2 \%$ among women aged 15 years to $28 \%$ among those aged 19 years (6).

Pregnancy at an early age is risky for the mother and the baby. Maternal conditions in adolescents cause $13 \%$ of all deaths and $23 \%$ of all Disability Adjusted Life Years (DALYs) (overall burden of disease due to pregnancy and childbirth among women of all ages). Moreover, babies born to adolescents also face a significantly higher risk of death compared to babies born to older women (7). Teenage pregnancy is the biggest killer of young girls worldwide; 1, 000, 000 teenage girls die or suffer serious injury, infection or disease due to pregnancy or childbirth every year (8). Adolescent girls aged 15 to 19 years are twice as likely to die from complications in pregnancy as are women in their twenties. The youngest girls are particularly at risk; the mortality rate for those under 15 is four times higher than for those in their 20s (9).

Teenage pregnancy also has significant long term social consequences for the adolescents, their children, their families and their communities; it led adolescents to less educational attainment and high school dropout, poor health and poverty. The children of teenage mothers are also more likely to have lower school achievement and drop out of high school, have more health problems, are incarcerated at some time during adolescence, give birth as a teenager, and face unemployment as a young adult $(3,11-13)$.

Although adolescent pregnancy occurs among all racial, cultural and socioeconomic groups, some adolescents are more likely than others to become pregnant (4). Factors such as economic status, education, religion, place of residence, peer's and partners' behaviours, family and community attitudes, age, mass media, lack of reproductive health services and knowledge are contributing factors to the increase of unintended pregnancy among adolescents in Ethiopia (14).

The government of Ethiopia developed strategies to achieve four major objectives: increasing access to quality reproductive health services for adolescents, increase awareness and knowledge about reproductive health issues, strengthen multisectoral partnerships, and design and implement adolescent and youth reproductive health programs. However, teenage pregnancy remains high in the country (15).

Studies on adolescent sexuality and pregnancy are very limited in our country particularly in the South Region. Therefore, this study was conducted with the aim of assessing the magnitude and identifying associated factors of teenage pregnancy among school adolescents of Arba Minch Town in order to contribute to the prevention programs by providing up-to-date information for decision-making and program implementation.

\section{METHODS AND MATERIALS}

Study setting: The study was conducted from 2030 March 2014 in Gammo Goffa Zone, Arba Minch Town, South Ethiopia. According to the latest national population projection based on the population and housing census, the total population of the town is about 103,965 people (16). The town has four sub-cities named: Secha, Abaya, Nechsar and Sikela. In the town, there are eight colleges (private and public), six high schools and two preparatory schools. 
An institution-based, cross-sectional study design was employed among female students in the age range of between 15 and 19 years from the four schools in the town. The sample size for the study was calculated considering $8 \%$ prevalence of adolescent pregnancy (17), 95\% certainty and $5 \%$ of margin of error between population and sample with non-response rate of $10 \%$. Therefore, the total calculated sample size for this study was 578 students. There were 8 schools (2 preparatory and 6 high schools) in the town. After stratifying schools into preparatory and high schools, one preparatory school and three high schools were selected randomly. Proportional numbers of students were assigned to each school and then the total number of 15-19 years old female students in each grade level was obtained from the school administration. A separate sampling frame was prepared for each grade level of each school. Then, the final participants were drawn from each grade level by systematic random sampling technique (1 in every 5 students) (Figure 1).

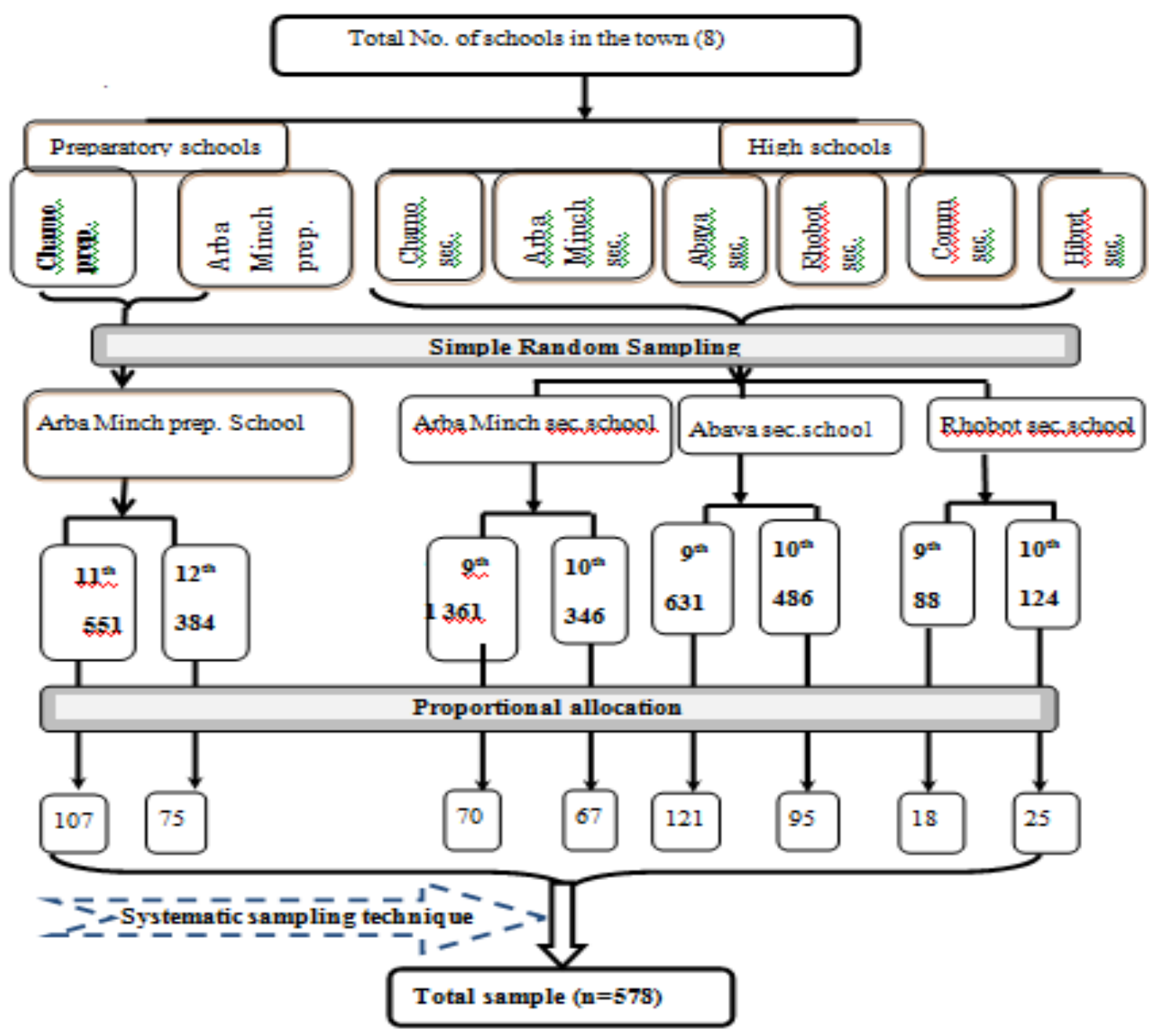

Figure 1: Schematic presentation of sampling procedure among schools in Arba Minch town, March 2014(n=578)

Data collection: Seven data collectors (all of them were college completed individuals working in different institutions) and two supervisors were recruited for data collection and supervision

DOI: http://dx.doi.org/10.4314/ejhs.v28i3.6 
respectively. Training on the methods, objectives, and other technical aspects of the study were provided to the data collectors and supervisors. A pre-tested, structured,self-administered questionnaire was used to collect the data. The questionnaire was prepared in English and then translated into the local language (Amharic), and then back translated into English language for its consistency. For the translation and back translation purpose, we used two different individuals who speak both English and Amharic fluently.

In order to ensure the quality of the data, pretesting of the questionnaire was done in the same set-up having similar age group but not from a selected high school. Some unclear and difficult questions to understand by most of the students were corrected and rephrased accordingly during the pretest.

The sitting arrangement of the students was considered; each student took a single seat with sparse arrangement of chairs and desks. Then after, the copies of questionnaire were distributed among students after short orientation had been provided. The principal investigator and the supervisors closely supervised the data collection process.

Data analysis: Data were analysed using SPSS V-20 statistical software. Assumptions for logistic regression and multi-collinearity diagnostics were checked. Descriptive statistics was used and the results were displayed using tables. The outcome variable was dichotomized as $0=$ no and $1=$ yes. Binary logistic regression was carried out. Firstly, bivariate analysis was done to see the crude effect of each independent variable on the outcome variable. Only those variables with $p$-value $<0.25$ were selected and entered into multivariate logistic regression analysis to identify the independent predictors. Adjusted odds ratio with its $95 \%$ confidence interval was used to identify factors independently associated with teenage pregnancy, and $\mathrm{p}$-values $<0.05$ were considered for statistical significance.

Ethical consideration: Ethical clearance was obtained from Jimma University Ethical Review
Committee. A formal letter was submitted to the Education office of the Gammo Goffa Zone and subsequently to high schools of Arba Minch Town where the study took place. Written permissions from the parents of the respondents were obtained a day before the time of data collection. Oral and written permissions from the schools and the respective study subjects were obtained.

\section{Operational definitions}

Ever pregnant: was measured by asking the respondent "Have you ever been pregnant?" which includes pregnancies that ended in live birth, still birth and abortion. Then, the response was categorized as $0=$ no and $1=$ yes.

Emergency contraceptives: As an emergency measure, women can take special pills to prevent pregnancy within three days after they have unprotected sexual intercourse.

Know the exact time to take emergency contraceptives: individuals who know the exact time of taking emergency contraceptives (within 72 hours after unprotected sexual intercourse)

Do not know the exact time to take emergency contraceptives: individuals who do not respond as per above.

Knowledge of fertile period in the menstrual cycle: Respondents were asked a 'yes-no' question, "Do you know the high risk days of your menstrual period to get pregnant?" and "when are those days in the menstrual period?". Then, the responses were categorized as $1=$ know (if she answers the letter of choice that contains the time 4 days before and after $14^{\text {th }}$ day of her first menstrual cycle) and $2=$ don't know (if otherwise ).

Parent-daughter interaction: was measured by asking the following four questions:

1. Do your parents communicate with you on issues related to sexuality, love and friendship openly?

2. Do your either parents know about your love or sexual partner?

3. Do your parents follow you where and with whom you stay when you are out of home?

DOI: http://dx.doi.org/10.4314/ejhs.v28i3.6 
4. Do your parents like your love and sexual relationship with a boyfriend

The median score from the four questions was computed (i.e.; 1 ) and levelled as ' $l=$ poor interaction (if scored $\leq 1$ ) and ' $2=$ good interaction (if scored $>1$ ).

\section{RESULTS}

A total of $560(96.9 \%)$ respondents with complete information were included in the analysis;

Table 1: Socio-economic characteristics and history of pregnancy among respondents in high school and preparatory schools of Arba Minch Town, March 2014( $\mathrm{n}=560)$.

\begin{tabular}{|c|c|c|c|c|}
\hline \multirow[t]{2}{*}{ Variables } & \multicolumn{4}{|c|}{ School type } \\
\hline & \multicolumn{2}{|c|}{ High school (349) } & \multicolumn{2}{|c|}{ Preparatory $(211)$} \\
\hline \multicolumn{5}{|l|}{ Age } \\
\hline $15-17$ & 260 & 74.5 & 42 & 19.9 \\
\hline $18-19$ & 89 & 25.5 & 169 & 80.1 \\
\hline \multicolumn{5}{|l|}{ Religion } \\
\hline Orthodox & 137 & 39.3 & 80 & 37.9 \\
\hline Protestant & 134 & 38.4 & 77 & 36.5 \\
\hline Muslim & 67 & 19.2 & 41 & 19.4 \\
\hline Others & 11 & 3.2 & 13 & 6.2 \\
\hline \multicolumn{5}{|l|}{ Ethnicity } \\
\hline Gamo & 196 & 56.2 & 98 & 46.4 \\
\hline Goffa & 65 & 18.6 & 46 & 21.8 \\
\hline Wolita & 44 & 12.6 & 26 & 12.3 \\
\hline Amhara & 19 & 5.4 & 19 & 9.0 \\
\hline Others & 25 & 7.2 & 22 & 10.4 \\
\hline \multicolumn{5}{|l|}{ Residence } \\
\hline Urban & 237 & 67.9 & 155 & 73.5 \\
\hline Rural & 112 & 32.1 & 56 & 26.5 \\
\hline \multicolumn{5}{|l|}{ Marital status } \\
\hline Single & 334 & 95.7 & 164 & 77.7 \\
\hline Married & 15 & 4.3 & 47 & 22.3 \\
\hline \multicolumn{5}{|c|}{ Ever been pregnant } \\
\hline Yes & 10 & 2.9 & 33 & 15.6 \\
\hline No & 339 & 97.3 & 178 & 84.6 \\
\hline
\end{tabular}

Fertility knowledge and pregnancy among sexually active school adolescents were assessed; from the total of 124 sexually active students, $43(34.7 \%)$ ever had history of pregnancy, and $47(37.9 \%)$ of them did not know the fertile days in their menstrual cycle. Seventy-eight $(62.9 \%)$ of
$397(70.9 \%)$ were from urban settings. Two hundred and seventeen $(38.8 \%)$ of the respondents were orthodox by religion, and Gamo was the major ethnic group accounting for $292(52.1 \%)$ of the total respondents. With regard to school type, $349(62.3 \%)$ of the respondents were high school students (grade $9 \& 10$ ) while the remaining, 211(37.7\%), were preparatory school students (grade 11 and 12) (Table 1). 
Table 2: Fertility knowledge and pregnancy among sexually active school adolescents in Arba Minch town, March 2014(n=124)

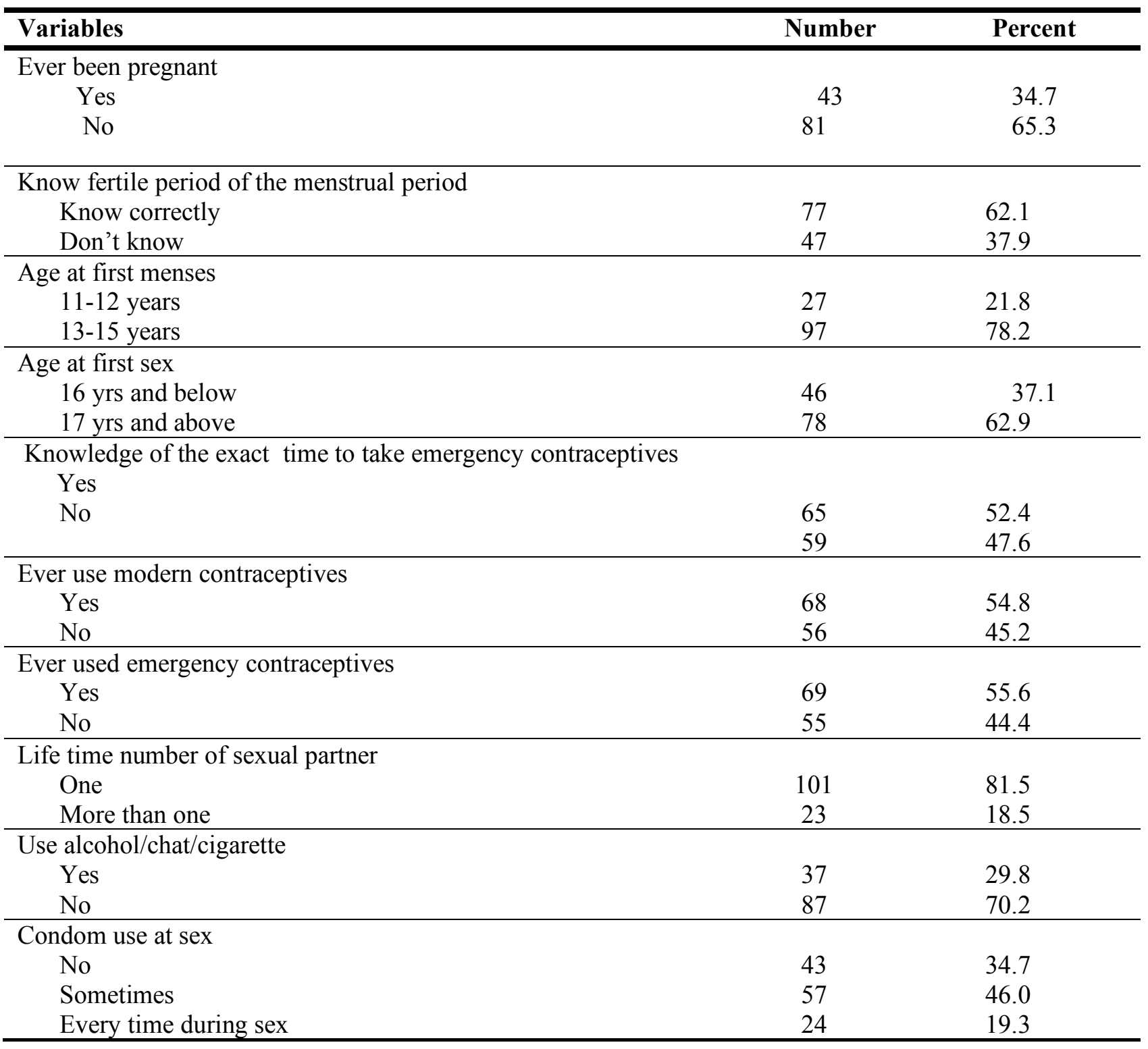

We assessed the family and peer level characteristic of the respondents; about $165(29.5 \%)$ of them reported that their mothers completed secondary education. The majority, $366(65.4 \%)$, of the respondents lived with both of their biological parents. Three hundred and twenty-eight $(63.2 \%)$ of them reported that they had poor parent-daughter interaction concerning issues of sexuality, love and pregnancy (Table 3 ).

DOI: http://dx.doi.org/10.4314/ejhs.v28i3.6 
Table 3: Family and peer level characteristics of respondents among school adolescents in Arba Minch Town, March $2014(\mathrm{n}=560)$

\begin{tabular}{|c|c|c|}
\hline Variables & Number & Percent \\
\hline $\begin{array}{l}\text { Educational status of the mother }(\mathrm{n}=559) \\
\text { No formal education } \\
\text { Primary education } \\
\text { Secondary education } \\
\text { College/university education }\end{array}$ & $\begin{array}{l}78 \\
163 \\
165 \\
153\end{array}$ & $\begin{array}{l}14.0 \\
29.2 \\
29.5 \\
27.3\end{array}$ \\
\hline $\begin{array}{l}\text { Occupation of the father }(\mathrm{n}=556) \\
\text { Gov't employee } \\
\text { Merchant } \\
\text { Farmer } \\
\text { Daily labourer } \\
\text { Other }\end{array}$ & $\begin{array}{c}168 \\
138 \\
106 \\
46 \\
98\end{array}$ & $\begin{array}{l}30.2 \\
24.8 \\
19.1 \\
8.3 \\
17.6\end{array}$ \\
\hline $\begin{array}{l}\text { Occupation of the mother }(\mathrm{n}=554) \\
\text { Housewife } \\
\text { Gov't employed } \\
\text { Merchant } \\
\text { Daily labourer } \\
\text { Other }\end{array}$ & $\begin{array}{c}185 \\
153 \\
131 \\
72 \\
13\end{array}$ & $\begin{array}{l}33.6 \\
27.8 \\
23.2 \\
13.0 \\
2.4\end{array}$ \\
\hline $\begin{array}{l}\text { Whom live with }(\mathrm{n}=560) \\
\text { Both biological parents } \\
\text { Either of biological parents } \\
\text { neither of biological parents }\end{array}$ & $\begin{array}{c}366 \\
104 \\
90\end{array}$ & $\begin{array}{l}65.4 \\
18.6 \\
16.0\end{array}$ \\
\hline $\begin{array}{l}\text { Parent-daughter interaction }(\mathrm{n}=519) \\
\text { Good interaction } \\
\text { Poor interaction }\end{array}$ & $\begin{array}{l}191 \\
328\end{array}$ & $\begin{array}{l}36.8 \\
63.2\end{array}$ \\
\hline $\begin{array}{l}\text { Occupation of the husband }(\mathrm{n}=62) \\
\text { Gov't employee } \\
\text { Merchant } \\
\text { Farmer } \\
\text { Daily labourer }\end{array}$ & $\begin{array}{l}17 \\
18 \\
14 \\
13\end{array}$ & $\begin{array}{l}27.4 \\
29.0 \\
22.6 \\
21.0\end{array}$ \\
\hline $\begin{array}{l}\text { Education status of the husband }(\mathrm{n}=62) \\
\text { No formal education } \\
\text { Primary education } \\
\text { Secondary education } \\
\text { College/university education }\end{array}$ & $\begin{array}{c}8 \\
17 \\
24 \\
13\end{array}$ & $\begin{array}{l}12.9 \\
27.4 \\
38.7 \\
21.0\end{array}$ \\
\hline
\end{tabular}

With regard to the prevalence of teenage pregnancy, $43(7.7 \%)$ of the respondents had history of pregnancy and only $12(27.9 \%)$ of those pregnancies were wanted. Multivariate logistic regression analysis was carried out. The overall significance of the model to predict the probability of teenage pregnancy was checked [2loglikelihood $=196.2$, model $\left.\mathrm{X}^{2}=94.1, \mathrm{df}=25\right]$ and the overall prediction of the model was $92.8 \%$. Being $11^{\text {th }}$ and $12^{\text {th }}$ grade levels, substance use (alcohol/chat/cigarette), not knowing the exact time to take emergency contraceptives, living

DOI: http://dx.doi.org/10.4314/ejhs.v28i3.6 
with either of biological parents, living with neither of biological parents and poor parentdaughter interaction were found to be significant predictors of teenage pregnancy in this study. However, marital status, religious participation, knowledge of fertile period of menstrual cycle and educational status of the respondents' mothers did not show significant associations with teenage pregnancy (Table 4).

Table 4: Bivariate and multivariate logistic regression analysis of factors affecting teenage pregnancy among school adolescents in Arba Minch Town, March 2014

\begin{tabular}{|c|c|c|c|c|}
\hline \multirow[b]{2}{*}{ Variables } & \multicolumn{2}{|c|}{ Ever pregnant $(\mathrm{N}=560)$} & \multirow[b]{2}{*}{$\operatorname{COR}(95 \% \mathrm{CI})$} & \multirow[b]{2}{*}{$\operatorname{AOR}(95 \% C I)$} \\
\hline & Yes (\%) & No $(\%)$ & & \\
\hline \multicolumn{5}{|l|}{ Grade level } \\
\hline $9^{\text {th }}$ & $8(4.0 \%)$ & $193(96.0 \%)$ & 1 & 1 \\
\hline $10^{\text {th }}$ & $9(5.0 \%)$ & $171(95.0 \%)$ & $1.2(0.47,3.36)$ & $1.4(0.81,1.42)$ \\
\hline $11^{\text {th }}$ & $16(15.2 \%)$ & $89(84.8 \%)$ & $4.3(1.8,10.5)$ & $4.6(1.4,9.3)^{*}$ \\
\hline $12^{\text {th }}$ & $10(13.5 \%)$ & $64(86.5 \%)$ & $3.8(1.4,10.0)$ & $5.8(1.3,14.1)^{*}$ \\
\hline \multicolumn{5}{|l|}{ Age group(yrs) } \\
\hline $15-17$ & $14(4.6 \%)$ & $288(95.4 \%)$ & 1 & 1 \\
\hline $18-19$ & $29(11.2 \%)$ & $229(88.8 \%)$ & $2.6(1.4,5.1)$ & $1.1(0.37,2.71)$ \\
\hline \multicolumn{5}{|l|}{ Marital status } \\
\hline Single & $31(6.3 \%)$ & $467(93.7 \%)$ & 1 & 1 \\
\hline Ever married & $12(17.4 \%)$ & $50(82.6 \%)$ & $3.6(1.7,7.5)$ & $1.5(0.55,3.96)$ \\
\hline \multicolumn{5}{|l|}{ Religious participation } \\
\hline Strong & $13(5.1 \%)$ & $241(94.9 \%)$ & 1 & 1 \\
\hline Weak & $18(7.5 \%)$ & $221(92.5 \%)$ & $1.5(0.7,3.1)$ & $1.2(0.61,1.31)$ \\
\hline No & $12(17.9 \%)$ & $55(82.1 \%)$ & $4.1(1.8,9.3)$ & $2.21(0.71,6.85)$ \\
\hline \multicolumn{5}{|l|}{ Know fertile period in menses } \\
\hline Yes & $29(11.5 \%)$ & $224(88.5 \%)$ & 1 & 1 \\
\hline No & $14(4.6 \%)$ & 293(95.4\%) & $0.3(0.2,0.6)$ & $0.56(0.25,1.27)$ \\
\hline \multicolumn{5}{|l|}{ Use alcohol/khat/cigarette } \\
\hline Yes & $21(19.4 \%)$ & $87(80.6 \%)$ & $4.7(2.5,9.0)$ & $3.1(1.1,8.8)^{*}$ \\
\hline No & $22(4.9 \%)$ & $430(95.1 \%)$ & 1 & 1 \\
\hline \multicolumn{5}{|c|}{$\begin{array}{l}\text { Knowledge of the exact time } \\
\text { to take emergency } \\
\text { contraceptives }\end{array}$} \\
\hline Yes & $19(5.9 \%)$ & $302(94.1 \%)$ & 1 & 1 \\
\hline No & $24(10.0 \%)$ & $215(90.0 \%)$ & $1.8(1.0,3.3)$ & $3.3(1.4,7.4)^{*}$ \\
\hline \multicolumn{5}{|l|}{$\begin{array}{l}\text { Educational status of the } \\
\text { mother }\end{array}$} \\
\hline No formal education & $10(12.8 \%)$ & $68(87.2 \%)$ & $3.6(1.3,10.3)$ & $1.9(0.55,6.74)$ \\
\hline Primary education & $18(11.0 \%)$ & $145(89.0 \%)$ & $3.0(1.2,7.9)$ & $1.3(0.28,6.07)$ \\
\hline Secondary education & $9(5.5 \%)$ & $156(94.5 \%)$ & $1.4(0.8,1.3)$ & $1.3(0.45,4.51)$ \\
\hline College/university & $6(3.9 \%)$ & $147(96.1 \%)$ & 1 & 1 \\
\hline \multicolumn{5}{|l|}{ Living arrangement } \\
\hline Both biological parents & $17(4.6 \%)$ & $349(95.4 \%)$ & 1 & 1 \\
\hline Either of bio. Parents & $12(11.5 \%)$ & $92(88.5 \%)$ & $2.7(1.2,5.8)$ & $3.3(1.2,9.5)^{*}$ \\
\hline Neither of bio. Parents & $14(15.6 \%)$ & $76(84.4 \%)$ & $3.8(1.8,8.0)$ & $3.1(1.1,8.7)^{*}$ \\
\hline \multicolumn{5}{|l|}{ Parent-daughter interaction } \\
\hline Good & $8(4.2 \%)$ & $183(95.8 \%)$ & 1 & 1 \\
\hline Poor & $33(10.1 \%)$ & $295(89.9 \%)$ & $2.6(1.2,5.7)$ & $3.7(1.3,10.2)^{*}$ \\
\hline
\end{tabular}

*Significant at $\mathrm{P}<0.05$

DOI: http://dx.doi.org/10.4314/ejhs.v28i3.6 


\section{DISCUSSION}

Teenage pregnancy is one of the most unfavourable and usually unplanned outcomes of adolescents' sexual activity. Teens are initiated to engage in unprotected sex early in life so that they are exposed to young parenthood. Many teens that become pregnant have to leave school; this has a long-term implication for them as individual, their family and their community. The prevalence of sexual activity in this study was 124 (22.1\%). This finding is consistent with studies conducted among school adolescents of two towns of Ethiopia: Gondar (23.5\%) and Nekemt (21.5\%). However, slightly lower than the findings from Ethiopian Demographic and Health Survey (EDHS 2011) report and a study conducted among school adolescents of Ilorin, Nigeria. The findings in these studies were $24.2 \%$ and $28.2 \%$ respectively(20-21). The discrepancy may be due to methodological variations: EDHS included adolescents in the community whereas this study focused only on high school adolescents. Furthermore, Socio-cultural difference is there with the case of Ilorin, Nigeria. Although the Ethiopian government has been working on sexual and reproductive health issues with especial focus on the youth (including teenagers) in schools and community at large, the current study has shown that a high number of school teenagers were practicing sexual intercourse and are still at risk of teenage pregnancy.

The overall prevalence of teenage pregnancy in this study was $43(7.7 \%)$. This finding is comparable with the finding from EDHS 2011 report of Southern Ethiopia Region which was $7.9 \%$ ( 20).

The prevalence of teenage pregnancy among sexually active students in this study was $34.7 \%$. This finding is comparable to the national figure reported by EDHS in which $34 \%$ of women were either mothers or pregnant with their first child by the age of 19 (20). The fiding in the current study a study is also inlines with the finding in Nigeria where $31.6 \%$ of adolescents who ever had sex experienced teenage pregnancy. However, it is much higher than the study conducted in the same country in Ilorin, Central Nigeria, among high school adolescents in which case only $5.7 \%$ of those sexually active female students had experienced teenage pregnancy (21). These variations may be due to the difference in age range of study populations as the study in Nigeria included adolescents of 10-19 years old whereas this study included those in the age range of 15-19 years (the probability of being pregnant is higher in the late adolescence stage than in early adolescence stage).

Regarding the factors contributing to teenage pregnancy, students from grades 11 and 12 were more likely to become pregnant compared to the students from grades 9 and 10. This finding is comparable with studies conducted in USA and Nekemt, Ethiopia, among school adolescents. In these studies, the prevalence of teenage pregnancy was generally increasing with increasing grade level (grades 9-12)(19,22). Other studies reported the inverse relationship between educational attainment and teenage pregnancy rate-the more years of schooling, the fewer early pregnancies $(7,23,24)$. However, the finding from this study contradicts this-adolescents in higher grade levels, $11^{\text {th }}$ and $12^{\text {th }}$, were significantly more likely to experience pregnancy than those in grades 9 and 10. This might be due to the longer stay at school, the higher exposure and probability of getting sexual relation among higher grade level students than lower grade students.

Substance is a gateway for risky sexual behaviours among adolescents which results in teenage pregnancy with consequent health and social implications. Because it constitutes a deviation from conventional behaviour, it is regarded as problem behaviour (25). Adolescents who used substance (alcohol/chat/cigarette) were more likely to experience teenage pregnancy compared to those who did not use. This finding is supported by the finding from a systematic review from the European Union Countries and a study conducted in South Africa which revealed that substance use was significantly associated with teenage pregnancy (26-27). This could be attributed to substance use or being under the influence of substance may influence the adolescent students to unrealistically appraise the situation and also impair their verbal as well as

DOI: http://dx.doi.org/10.4314/ejhs.v28i3.6 
physical resistance against unprotected sexual intercourse. Hence, the risk of teenage pregnancy is high.

The fact that having knowledge of the exact time when to take contraceptives prevents unwanted pregnancy is strongly supported by the finding from this study. The probability of experiencing pregnancy among those who know the exact time of emergency contraceptives was about $6 \%$, but it was $10 \%$ for those who do not know. The odds of being pregnant was about three times much higher among adolescents who do not know the exact time when to take emergency contraceptives than among their counterparts. According to the report by WHO, lack of knowledge about sex and family planning and lack of skills to put that knowledge into practice put adolescents at risk of pregnancy (7).

In this study, the risk of teenage pregnancy among adolescents who were living with either of biological parents and neither of their biological parents was higher as compared to those who were living with both biological parents. This result is in line with studies conducted among adolescents in Mechakal District, Ethiopia, a study from USA and a WHO report which showed that living with both biological parents has a protective effect on the occurrence of teenage pregnancy $(17,28-29)$. The reason could be that teens that live with biological parents are guided and get support and follow-up from their families so that they are under fence of protection that minimizes their chance of exposure to sexual experiences. Moreover, biological parents are highly responsible for their children's adoption of safer behaviours.

Parents play a critical role in the growth, development and sexual socialization of their children. Parental involvement through parentchild sexual communication presents education about sex and reproductive health to young people. Moreover, it promotes adolescents' selfesteem, transfer of sexual values, beliefs, information and expectations to their children with the aim of influencing sexual behaviours, attitudes and decision-making of their children to prevent risky behaviours and teenage pregnancy (30-33).

In this study, adolescents who were living in poor parent-daughter interaction conditions regarding issues of sexuality, love and pregnancy were 3.7 times more likely to experience pregnancy compared to those who lived under good parent-daughter interaction conditions. This finding is supported by a study in conducted British Columbia which reported that parentdaughter interaction concerning sexuality and reproductive health was significantly associated with teenage pregnancy (34). The possible explanation could be that female students who have good parent-daughter interaction may get good opportunity to have free discussion about sexuality and reproductive health issues thereby transfer of life skill is possible to protect themselves from teenage pregnancy.

Our study has limitations. From the very nature of the study, it assesses personal and sensitive issues related to sexual behaviours which might have caused underreporting of teenage pregnancy experiences. Thus, the findings of this study should be interpreted within these limitations.

In conclusion, the prevalence of teenage pregnancy among school adolescents is high to cause reproductive health and socio-economic challenges to adolescents in the study area. Being $11^{\text {th }}$ and $12^{\text {th }}$ grade student, substance use, not knowing the exact time to take emergency contraceptives, living arrangement and poor parent-daughter interaction were found to be significant predictors of teenage pregnancy. Special emphasis particularly in the areas of parent-daughter communication on the issues of sexuality and reproductive health, benefits of contraceptive use, and risk of substance use (alcohol, chat and cigarette smoking) are recommended.

\section{ACKNOWLEDGEMENTS}

We are very thankful to Jimma University College of Public Health and Medical Sciences for the financial support. Our special thanks go to the study participants for their response and time

DOI: http://dx.doi.org/10.4314/ejhs.v28i3.6 
to complete the questionnaire. Last but not least, we would like to thank the school directors of Arba Minch Town for arranging time and place for data collection.

\section{REFERENCES}

1. WHO. Programming for adolescent health and development. Report of HO/UNFPA/UNICEF study group on programming for adolescents health. Geneva, WHO, 1999.

2. Kyei, K.A. Teenage Fertility in Vhembe District in Limpopo Province: How High is that? Journal of Emerging Trends in Economics and Management Sciences (JETEMS). 2012; 3(2):134-140.

3. WHO. Mps NOTES: Adolescent pregnancy. Department of Making Pregnancy Safer. Geneva, Switzerland:2008 Available at http://www.who.int/maternal_child_adolescen t/mpsnnotes 2 lr.pdf Contract No.: 1 .

4. Clifton D, Hervish A. the world's youth 2013 data sheet: Teenage Pregnancy and Childbearing. Washington, DC: Population Reference Bureau, 2013.

5. Singh S. Adding It Up: The Costs and Benefits of Investing in Family Planning and Maternal and Newborn Health. New York: Guttmacher Institute and United Nations Population Fund, 2009.

6. CSA. Ethiopia Demographic and Health Survey 2016. Addis Ababa, Ethiopia and Calverton, Maryland, USA, 2016.

7. WHO. Sixty-Fifth World Health Assembly:Provisional agenda item 13.4: Early marriages, adolescent and young pregnancies: Report by the Secretariat. 16, March 2012.

8. YWCA. Young Women's Leadership: Global Facts. Geneva, Switzerland avilable at: www.worldywca.org.

9. Presler-Marshall E, Jones N. Save The Children: Charting The Future: Empowering girls to prvent early pregnancy. London, UK: Overseas Development Institute, July 2012. http://www.who.int/maternal_child_adolescen t/mpsnnotes_2_lr.pdf Contract No.: 1 .
10. CDC. National Campaign to Prevent Teen and Unplanned Pregnancy, Counting It Up: The Public Costs of Teen Childbearing, 2011.

11. Perper K, Peterson K, Manlove J. Diploma Attainment Among Teen Mothers. Child Trends, Fact Sheet Publication \#2010-01: Washington, DC: Child Trends. 2010.

12. Hoffman S. By the Numbers: The Public Costs of Teen Childbearing. Washington, DC: National Campaign to Prevent Teen Pregnancy, 2006.

13. Hoffman S. Kids Having Kids: Economic Costs and Social Consequences of Teen pregnancy. Washington, DC: The Urban Institute Press; 2008.

14. Nalenga GZ. Causes of unintended pregnancy among adolescents in Addis Ababa, Ethiopia : Norwegian University of Life Sciences; May 2012.

15. FMOH. National Reproductive Health Strategy 2006 - 2015. In: Family Health Department $\mathrm{MoH}$, editor. Addis Ababa, Ethiopia, March 2006.

16. Central Statistical Authority of Ethiopia (CSA). Population and housing Census of Ethiopia: statistical Abstract. Addis Ababa; Ethiopia: CSA; 2007. p. 7-8.

17. Amanuel AA, Seme A. Reproductive Health Knowledge and Services Utilization among Rural Adolescents in Machakal district, Northwest Ethiopia. Asian Journal of Pharmacy, Nursing and Medical Sciences. June 2013; 01(01):25-37.

18. Feleke SA, Koye DN, Demssie AF, Mengesha ZB. Reproductive health service utilization and associated factors among adolescents (15--19 years old) in Gondar town, NorthWest Ethiopia. BMC health services research. 2013;13:294.

19. Seme A, Wirtu D. Premarital sexual practice among school adolescents in Nekemte town. Ethiop J Health Dev. 2008;22(2):168-73.

20. CSA. Ethiopia Demographic and Health Survey 2011. Addis Ababa, Ethiopia and Calverton, Maryland, USA, 2012.

21. Aderibigbe SA, Araoye MO, Akande TM, Musa OI, Monehin JO, Babatunde OA. Teenage Pregnancy and Prevalence of

DOI: http://dx.doi.org/10.4314/ejhs.v28i3.6 
Abortion among In-school Adolescents in North Central, Nigeria. Asian Social Science. January 2011;7(1):122-7.

22. CDC. Centers for Disease Control and Prevention, Youth Risk Behavior Surveillance-United States, 2011, MMWR. Atlanta: U.S. Department of Health and Human Services, June 8, 2012.

23. KNBS. Kenya National Bureau of Statistics and ICF Macro, Kenya Demographic and Health Survey 2008-09. Calverton, Maryland: KNBS and ICF Macro. 2010.

24. Gurmu E, Dejene T. Levels, Trends and Differentials of Adolescent Motherhood in Ethiopia: Evidences from 2005 EDHS. Afr $J$ Reprod Health. 2012;16(4):162-74.

25. Chassin L, Pressona C, Morgan-Lopezb A, Shermanc SJ: Devianceproneness" and adolescent smoking 1980 versus 2001: Has there been a hardening of adolescent smoking? Journal of Applied Developmental Psychology. 2007; 28(3):264-276

26. Imamura $M$, Tucker J, Hannaford $P$, da Silva MO, Astin M, Wyness L, et al. Factors associated with teenage pregnancy in the European Union countries: a systematic review. The European Journal of Public Health. 2007;17(6):630-6.

27. Madondo TT. Overview on Adolescence pregnancies and their impact on communities. pretoria, South Africa: 2013.

28. Martinez G, Copen CE, Abma JC. Teenagers in the United States: Sexual activity, contraceptive use, and childbearing, 20062010 National Survey of Family Growth: National Center for Health Statistics. Vital Health Stat 23(31). 2011 Retrieved from http://www.cdc.gov/nchs/data/series/sr_23/sr2 3_031.pdf Nov 13, 2013.

29. WHO. Risk and protective factors affecting adolescent reproductive health in developing countries: An analysis of adolescent sexual and reproductive health literature from around the world. Geneva: WHO, 2004.

30. Jerman P, Constantine NA. Demographic and psychological predictors of parent-adolescent communication about sex: a representative statewide analysis. J Youth Adolesc. 2010; 39(10):1164-74.

31. Martino SC, Elliott MN, Corona $\mathrm{R}$ et al. Beyond the "Big Talk": The Roles of Breadth and Repition in Prent-Adolescent Communication about Sexual Topics. Pediatrics. 2008;121:e612-e618.

32. Lefkowitz ES, Stoppa TM. Positive sexual communication and socialization in the parent-adolescent context. New Dir Child Adolesc Dev. 2006; 112:39-55.

33. Eisenberg ME, Sieving RE, Bearinger LH, Swain C, Resnick MD. Parents' communication with adolescents about sexual behavior: a missed opportunity for prevention? J Youth Adolesc. 2006; 35 (6):893-902

34. Moretti M, Peled M. Adolescent-parent attachment: Bonds that support healthy development. Paediatr Child Health. 2004;9(8):551-5.

DOI: http://dx.doi.org/10.4314/ejhs.v28i3.6 